\title{
Bone Marrow Stem Cell with Potential for Megakaryocytic and Erythroid Differentiation
}

National Cancer Institute

\section{Source}

National Cancer Institute. Bone Marrow Stem Cell with Potential for Megakaryocytic and Erythroid Differentiation. NCI Thesaurus. Code C43225.

An undifferentiated cell which can undergo division and can give rise to either a megakaryocyte or a cell in the erythrocytic series. 